\title{
Tumor cDNA Expression Profile
}

National Cancer Institute

\section{Source}

National Cancer Institute. Tumor cDNA Expression Profile. NCI Thesaurus. Code C129771.

An analysis of all of the complementary DNA molecules expressed in by a tumor. 